\title{
ANALISIS PENGARUH PERSEPSI KEMUDAHAN, RISIKO, FITUR LAYANAN TERHADAP KEPUTUSAN NASABAH PENGGUNA INTERNET BANKING (STUDI KASUS BRI SYARIAH PUSAT)
}

\section{ANALYSIS ON INFLUENCE OF PERCEPTION OF CONVENIENCE, RISK, SERVICES FEATURES ON CUSTOMERS DECISION IN USER THE INTERNET BANKING (CASE STUDY ON BRI SYARIAH CENTER)}

\author{
Arif Pribadi ${ }^{1)}$; Rachmat Gunawan ${ }^{2)}$ \\ ${ }^{1)}$ UIN Syarif Hidayatullah; ${ }^{2)}$ Universitas Djuanda \\ Correspondence Author: arifpribadi16@gmail.com
}

\begin{abstract}
This research to analyze The Costumer"s Decision In Using The Internet Banking Is Based on The Perception of Convenience, Risk, and Service Features at BRI Syariah banks. Sampling method used is purposive sampling. Respondents are 100 people who have the internet banking service application at the BRI Syariah bank. The Analysis method is multiple linear regression. The customer decision in using internet banking BRI Syariah partially and simultaneusly. Is influenced as significant by the perception ease of use, risk and services features.
\end{abstract}

Keywords: Perception of Convenience, Risk, Service Features, Decision Process, Internet Banking, Bank BRI Syariah

\begin{abstract}
ABSTRAK
Analisa Keputusan Nasabah pengguna internet banking berdasarkan pengaruh persepsi kemudahan, risiko dan fitur layanan pada bank BRI Syariah Pusat. Metode purposive sampling yang digunakan dalam penelitian ini. Responden adalah pemilik aplikasi layanan internet banking BRI Syariah Pusat yang diteliti dalam penelitian ini. Metode analisis adalah regresi linear berganda. Keputusan Nasabah dalam pengguna internet banking di Bank BRI Syariah dipengaruhi oleh Persepsi Kemudahan, Resiko, dan Fitur yang merupakan hasil penelitian ini

Kata Kunci: Keputusan Nasabah, Persepsi kemudahan, resiko dan fitur layanan Internet Banking, Bank BRI Syariah

\section{PENDAHULUAN}

Fasilitas layanan internet banking dapat diakses 24 jam selama terdapat koneksi internet. Dapat digunakan kapan dan dimanapun berada dengan memakai laptop, smartphone dan personal computer. Dengan

adanya internet banking memberi kemudahan, keamanan serta kenyamanan dalam bertransaksi sonline sehingga banyak digemari oleh nasabah, dapat dibuktikan dengan data jumlah pengguna internet banking di Indonesia. Seperti dijelaskan pada Gambar 1.1 di bawah ini
\end{abstract}




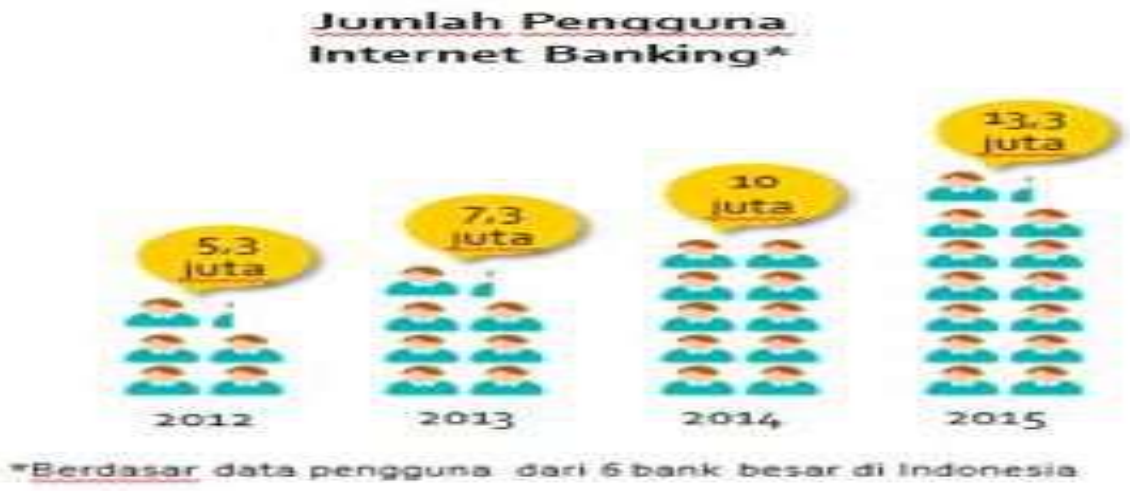

Gambar 1. Jumlah Pengguna internet banking

Sumber: sharingvision.com (2016:1)

Pada Gambar 1. diketahui bahwa jumlah pengguna internet banking pada tahun 2012 sebesar 5,3 juta, pada tahun 2013 sebesar 7,3 juta pengguna, tahun 2014 sebesar 10 juta pengguna, dan tahun 2015 sebesar 13,3 juta. Disini terlihat peningkatan setiap tahunnya dari tahun 2012-2015, yaitu
5,3 juta pengguna di tahun 2012 menjadi 13,3 juta pengguna pada tahun 2015 .

Berdasarkan hasil data yang didapat oleh similarweb.com yang mendasarkan diri pada jumlah kunjungan web pada subdomain internet banking web BRI Syariah ternyata hasilnya mengalami penurunan.

\section{SimilarWeb Feee Repart on Any Webste or App a d}

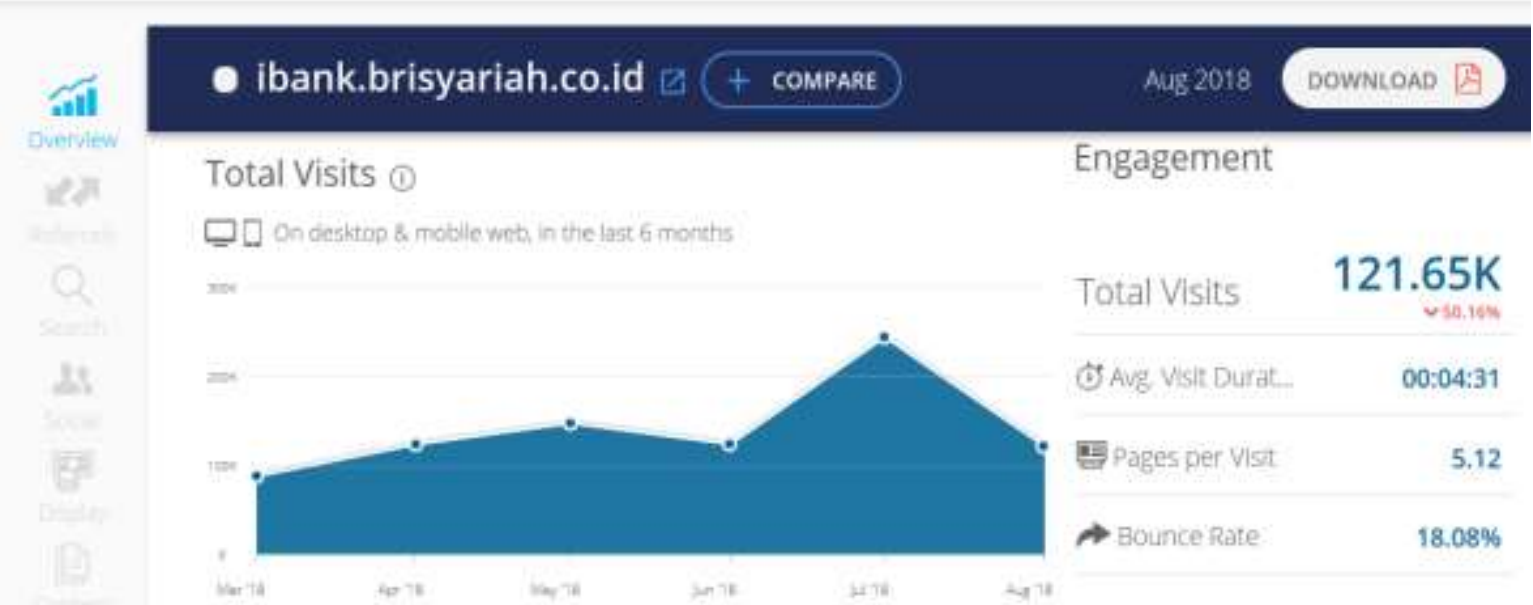

\section{Gambar 2. Total Visits ibank.brisyariah.co.id}

Sumber: similarweb.com

Fenomena pertama, pada Gambar 2. dari data yang diperoleh similarweb.com mengenai total visits bahwa total visits subdomain internet banking web BRI Syariah mengalami penurunan dari bulan bulan sebelumya. Artinya pengunjung subdomain internet banking situs web BRI Sya riah menurun dari bulan juli 2018 hingga bulan agustus 2018 yaitu kunjungan sebesar 244.081 menurun $50,16 \%$ dengan total kunjungan sebesar 121.650.

Fenomena kedua, kemudian adanya fenomena yang di dapatkan melalui PraSurvey yang di lakukan kepada 30 nasabah BRI Syariah, yaitu 23 nasabah mengetahui adanya fasilitas internet banking BRI 
Syariah, akan tetapi hanya 12 nasabah saja pengguna internet banking.

Fenomena ketiga, berdasarkan laporan keberlanjutan BRI Syariah tahun 2016 jumlah nasabah BRI Syariah sebanyak 1.591.242 sedangkan untuk pengguna internet banking menurut laporan tahunan BRI Syariah sebanyak 27.023. Artinya hanya $1,69 \%$ saja nasabah pengguna internet banking di BRI Syariah.

\section{MATERI DAN METODE}

\section{Persepsi Kemudahan}

Menurut Widjana (2010:33), persepsi kemudahan penggunaan (perceived ease of use) persepsi kemudahan penggunaan sistem teknologi informasi tidak akan merepotkan atau membutuhkan usaha yang besar pada saat digunakan (free of effort).

Menurut Sun dan Zhang. (2006:644) indikator untuk mengukur persepi kemudahan pengguna adalah sebagai berikut:

a) Mudah untuk digunakan

b) Mudah untuk dipahami

c) Jelas dan dapat dimengerti

\section{Risiko}

Menurut Yudha (2015:4), risiko adalah suatu keadaan tidak pasti yang dipertimbangkan orang untuk memutuskan atau bertransaksi online. Pertimbangan tersebut berupa jarak dan suasana impersonal bertransaksi online dan infrastruktur global yang mengandung banyak unsur risiko.

Menurut Amijaya (2010:29), risiko yang ditimbulkan jika transaksi pengguna internet banking yaitu diukur dengan indikator:
a) Besarnya risiko
b) Keamanan transaksi
c) Kebutuhan transaksi
d) Jaminan keamanan dari bank

\section{Fitur Layanan}

Menurut Schmitt (2010:45) fitur adalah karakteristik yang menambah fungsi dasar suatu produk. Karena fitur ini menjadi alasan konsumen untuk memilih suatu produk, maka bagi pemasar tradisional fitur adalah alat kunci untuk mendiferensiasikan produk mereka dengan produk pesaing.

Menurut Poon dalam Pranidana (2010:22), indikator ketersediaan fitur (feature availability) suatu sistem internet banking, yaitu:

a) Kemudahan memperoleh informasi terkait produk dan jasa

b) Keberagaman layanan transaksi

c) Keberagaman fitur

d) Inovasi produk

\section{Keputusan Nasabah}

Menurut Kotler \& Keller (2007:240), keputusan pembelian adalah preferensi konsumen atas merek-merek yang ada di dalam kumpulan pilihan. Suatu keputusan (decision) melibatkan pilihan diantara dua atau lebih alternatif tindakan atau perilaku. Keputusan selalu mensyaratkan pilihan diantara beberapa perilaku yang berbeda. Pada intinya, pengambilan keputusan konsumen adalah proses pengintegrasian yang mengkombinasikan pengetahuan untuk mengevaluasi dua perilaku alternatif atau lebih, dan memilih salah satu diantaranya (Setiadi, 2015:341). Menurut Umar (2014:7) indikator keputusan nasabah dalam melakukan transaksi di internet banking antara lain:

a) Mudah dioperasionalkan

b) Menguntungkan

c) Menyesuaikan dengan kebutuhan

d) Biaya pengguna lebih ekonomis

\section{Kerangka Pemikiran}

Berikut ini adalah gambar yag memperlihatkan kerangka pemikiran dari penelitian ini: 


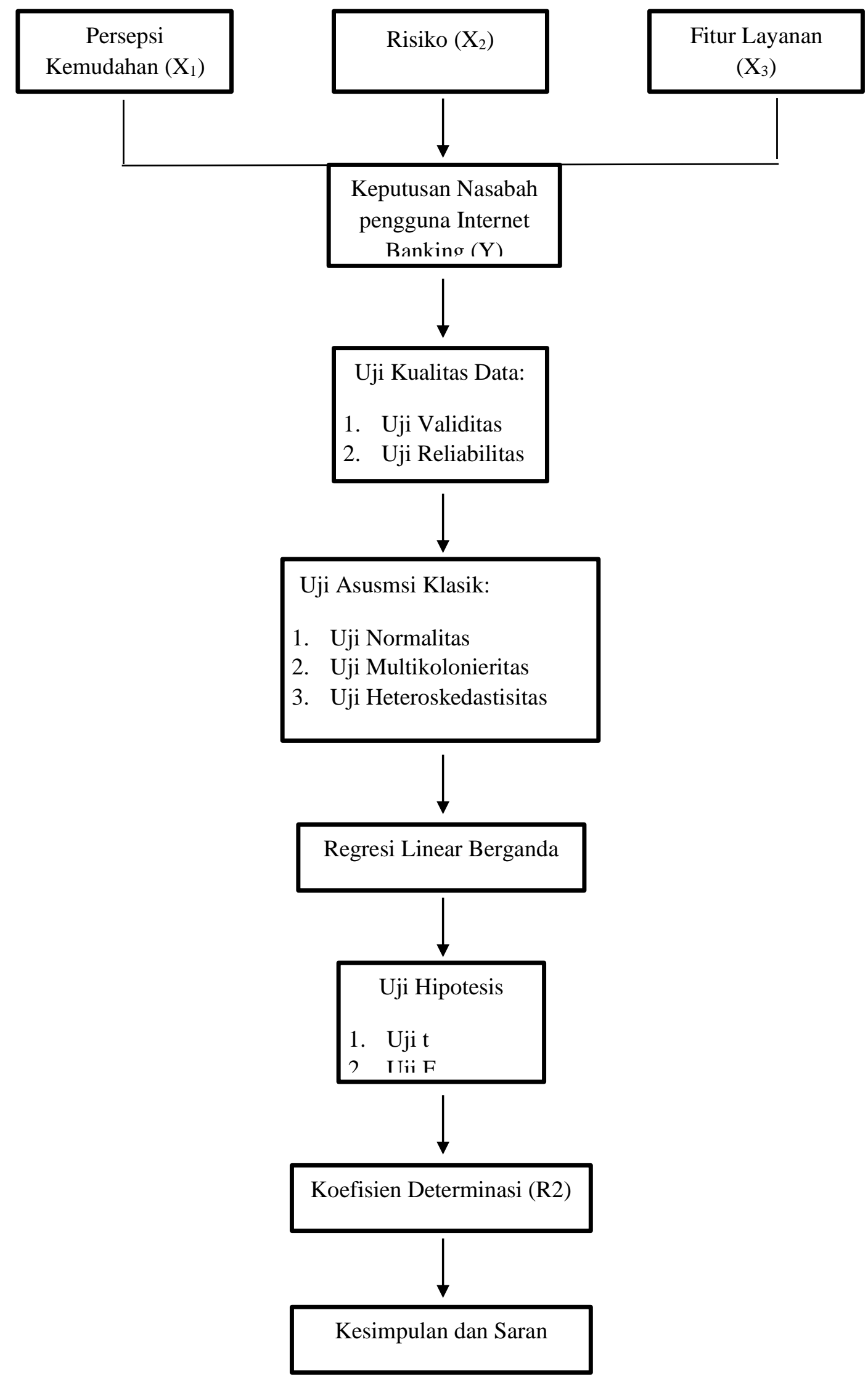

Gambar 3. Kerangka Pemikiran 


\section{METODE PENELITIAN}

\section{Klasifikasi Sampel}

Menurut Sugiyono (2015:82), teknik pengambilan sampel yang digunakan oleh penulis adalah metode purposive sampling, yaitu teknik pengambilan sampel sumber data dengan pertimbangan tertentu. Pengambilan sampel penelitian ini adalah nasabah BRI Syariah pengguna internet banking BRI Syariah.

\section{Data Penelitian}

Data yang digunakan dalam penelitian ini pengguna data primer, yaitu data yang diperoleh secara langsung dari responden dengan cara menyebarkan kuesioner kepada pengguna internet banking untuk mengetahui hubungan antara persepsi kemudahan, risiko, fitur layanan terhadap keputusan nasabah pengguna internet banking pada BRI Syariah Pusat.

\section{Identifikasi Variabel}

Menurut Sugiyono (2017:8), metode penelitian kuantitatif adalah metode untuk meneliti populasi atau sampel tertentu, teknik pengambilan sampel umumnya dilakukan secara random, pengumpulan data menggunakan instrumen penelitian, analisis data bersifat kuantitatif dengan tujuan untuk menguji hipotesis yang telah ditetapkan.

\section{HASIL DAN PEMBAHASAN}

Hasil penelitian disajikan dalam Tabel 1 di bawah ini

\section{Tabel 1. Hasil Pengujian Regresi Secara Parsial}

\begin{tabular}{|c|c|c|c|c|c|c|}
\hline \multicolumn{7}{|c|}{ Coefficients $^{\mathbf{a}}$} \\
\hline \multirow{2}{*}{\multicolumn{2}{|c|}{ Model }} & \multicolumn{2}{|c|}{$\begin{array}{c}\text { Unstandardized } \\
\text { Coefficients }\end{array}$} & \multirow{2}{*}{$\begin{array}{c}\text { Standardized } \\
\text { Coefficients }\end{array}$} & \multirow[b]{2}{*}{$\mathrm{t}$} & \multirow[b]{2}{*}{ Sig. } \\
\hline & & $\mathrm{B}$ & Std. Error & & & \\
\hline \multirow[t]{4}{*}{1} & (Constant) & ,507 & 1,372 & & ,369 & ,713 \\
\hline & $\begin{array}{l}\text { Persepsi } \\
\text { Kemudahan }\end{array}$ &, 254 & ,088 & ,204 & 2,899 & ,005 \\
\hline & Risiko &, 159 & ,071 &, 152 & 2,245 & ,027 \\
\hline & $\begin{array}{l}\text { Fitur } \\
\text { Layanan }\end{array}$ & ,639 & ,067 & ,633 & 9,531 & ,000 \\
\hline
\end{tabular}

a. Dependent Variable: Keputusan

Berdasarkan Tabel 1 di atas, maka dapat dijelaskan sebagai berikut:

1) Diketahui bahwa thitung persepsi kemudahan 2,899, sedangkan $\mathrm{t}_{\text {Tabel }}$ dapat dihitung $a=0,05$, karena menggunkan hipotesis dua arah, ketika mencari $\mathrm{t}_{\text {Tabel, }}$ nilai $a$ dibagi dua menjadi 0,025 serta $\mathrm{df}=\mathrm{n}-2$ menjadi $\mathrm{df}$ $=100-2=98$, dan didapat nilai $\mathrm{t}_{\text {Tabel }}$ sebesar 1,984. Sehingga hasil yang didapat $\mathrm{t}_{\text {hitung }}>\mathrm{t}_{\text {Tabel }}$ dimana $2,899>$ 1,984 dan nilai probabilitas signifikan $0,005<0,05$ sehingga $\mathrm{H}_{0}$ ditolak. Hal ini berarti persepsi kemudahan secara parsial berpengaruh signifikan terhadap keputusan nasabah pengguna internet banking.

2) Diketahui bahwa thitung risiko 2,245, sedangkan $\mathrm{t}_{\text {Tabel }}$ dapat dihitung $a=$ 0,05, karena menggunakan hipotesis dua arah, ketika mencari $\mathrm{t}_{\text {Tabel }}$, nilai $a$ dibagi dua menjadi 0,025 serta $\mathrm{df}=\mathrm{n}$ 2 menjadi $\mathrm{df}=100-2=98$, dan didapat nilai $\mathrm{t}_{\text {Tabel }}$ sebesar 1,984. Sehingga hasil yang didapat $t_{\text {hitung }}>t_{\text {Tabel }}$ dimana 2,245 $>1,984$ dan nilai probabilitas signifikan $0,27<0,05$ sehinga $\mathrm{H}_{0}$ ditolak. Hal ini berarti risiko secara parsial berpengaruh signifikan 
terhadap keputusan nasabah pengguna internet banking.

3) Diketahui bahwa thitung fitur layanan 9,531, sedangkan $\mathrm{t}_{\text {Tabel }}$ dapat dihitung $a$ $=0,05$, karena menggunakan hipotesis dua arah, ketika mencari $\mathrm{t}_{\text {Tabel, }}$, nilai $a$ dibagi dua menjadi 0,025 serta $\mathrm{df}=\mathrm{n}$ 2 menjadi df $=100-2=98$, dan didapat nilai tTabel sebesar 1,984. sehingga hasil yang didapat $t_{\text {hitung }}>\mathrm{t}_{\text {Tabel }}$ dimana 9,531 $>1,984$ dan nilai probabilitas signifikan
$0,000<0,05$ sehingga $\mathrm{H}_{0}$ ditolak. Hal ini berarti fitur layanan secara parsial berpengaruh signifikan terhadap keputusan nasabah pengguna internet banking.

\section{Hasil Pengujian Regresi Secara Simultan}

Adapun hasil pengujian regresi secara simultan dengan menggunakan $\mathrm{Uji} F$ tercantum pada Tabel 2. di bawah ini.

Tabel 2. Pengujian Regresi Secara Simultan

\begin{tabular}{|ll|r|r|r|r|c|}
\hline \multicolumn{7}{|c|}{ ANOVA $^{\text {a }}$} \\
\hline \multirow{2}{*}{ Model } & & $\begin{array}{c}\text { Sum of } \\
\text { Squares }\end{array}$ & df & Mean Square & F & Sig. \\
\hline & Regression & 193,280 & 3 & 64,427 & 60,100 &, $000^{\mathrm{b}}$ \\
& Residual & 102,910 & 96 & 1,072 & & \\
& Total & 296,190 & 99 & & & \\
\hline
\end{tabular}

a. Dependent Variable: Keputusan

b. Predictors: (Constant), Fitur Layanan, Risiko, Persepsi Kemudahan

Berdasarkan hasil uji Anova atau uji $\mathrm{F}$ dapat dilihat berdasarkan data di atas didapatkan dari nilai $f_{\text {hitung }} 60,100$, sedangkan $\mathrm{f}_{\text {Tabel }}$ dalam penelitian ini dimana $\mathrm{df}_{1}=\mathrm{k}-1$, dan $\mathrm{df}_{2}=\mathrm{n}-\mathrm{k}$, yang dimana dalam penelitian ini jumlah variabel independen 3 dan variabel dependen 1 serta jumlah sampel penelitian 100, sehingga $\mathrm{df}_{1}=4-1=3$ dan $\mathrm{d}_{2}=$ $100-4=96$, jadi, dapat dilihat $\mathrm{f}_{\text {Tabel }}$ pada penelitian ini 2,70, sehingga dapat disimpulkan 60,100 > 2,70, dan probabilitas signifikan pada penelitian ini $0,000<0,05$ sehingga $\mathrm{H}_{0}$ ditolak, yaitu persepsi kemudahan, risiko dan fitur layanan berpengaruh secara simultan terhadap keputusan nasabah pengguna internet banking.

\section{Uji Koefisien Determinasi $\left(\mathbf{R}^{2}\right)$}

Adapun hasil analisis koefisien korelasi dapat dilihat Tabel 3 di bawah ini:

Tabel 3. Hasil Analisis Koefisien Korelasi

\begin{tabular}{|l|c|r|r|r|}
\hline Model & R & R Square & $\begin{array}{c}\text { Adjusted R } \\
\text { Square }\end{array}$ & Std. Error of the Estimate \\
\hline 1 &, $808^{\mathrm{a}}$ &, 653 &, 642 & 1,03537 \\
\hline
\end{tabular}

a. Predictors: (Constant), Fitur Layanan, Risiko, Fitur Layanan

Berdasarkan Tabel 3 di atas menunjukkan bahkoefisien determinasi Adjusted $R^{2}$ sebesar 0,642 berarti kemampuan variabel bebas variabel dependen keputusan nasabah dapat dijelaskan oleh ketiga variabel independen, persepsi kemudahan, risiko, fitur layanan dalam menjelaskan varians dari variabel terikatnya adalah sebesar $64,2 \%$. Berarti terdapat $\quad 35,8 \% \quad(100 \%-64,2 \%) \quad$ varians variabel terikat dijelaskan oleh faktor lain yang tidak termasuk ke dalam persamaan regresi dalam penelitian ini. 


\section{Kesimpulan}

1. Persepsi kemudahan secara parsial dan signifikan berpengaruh terhadap keputusan nasabah pengguna internet banking di BRI Syariah Pusat.

2. Risiko secara parsial dan signifikan berpengaruh terhadap keputusan nasabah pengguna internet banking di BRI Syariah Pusat.

3. Fitur layanan secara parsial dan signifikan berpengaruh terhadap keputusan nasabah pengguna internet banking di BRI Syariah Pusat.

4. Persepsi kemudahan, risiko, fitur layanan secara simultan dan signifikan berpengaruh terhadap keputusan nasabah pengguna internet banking di BRI Syariah Pusat.

\section{Saran}

1. Bagi Perusahaan

a. Berdasarkan hasil penganalisaan deskriptif dari item pernyataan pada indikator layanan internet banking BRI Syariah jelas dan dapat dimengerti, banyak nasabah menyatakan tidak setuju, dapat diartikan bahwa nasabah menganggap layanan internet banking BRI Syariah tidak terlalu jelas dan dapat di mengerti. Oleh karena itu, BRI Syariah diharapkan dapat memberikan akses informasi dan edukasi yang mudah dimengerti oleh nasabah sehingga dapat meningkatkan pemanfaatan penggunaan internet banking.

b. Berdasarkan hasil penganalisaan deskriptif dari item pernyataan pada indikator layanan internet banking BRI Syariah jelas dan dapat dimengerti, banyak nasabah menyatakan tidak setuju, dapat diartikan bahwa nasabah menganggap layanan internet banking BRI Syariah tidak terlalu jelas dan dapat di mengerti. Oleh karena itu, BRI Syariah diharapkan dapat memberikan akses informasi dan edukasi yang mudah dimengerti oleh nasabah sehingga dapat meningkatkan pemanfaatan penggunaan internet banking.

c. Berdasarkan hasil penganalisaan deskriptif dari item pernyataan pada indikator layanan internet banking BRI Syariah memiliki keberagaman fitur, banyak nasabah menyatakan tidak setuju, dapat diartikan bahwa nasabah menganggap layanan internet banking BRI Syariah tidak terlalu memiliki keberagaman fitur. Oleh karena itu, BRI Syariah diharapkan dapat menambahkan fitur-fitur baru seperti fitur investasi.

2. Bagi Peneliti

Diharapkan bagi akademisi untuk terus dilakukan penelitian secara berlanjut dengan menggunakan variabel-variabel lainnya untuk pengembangan penelitian dan menambah referensi baru sebagai bahan perbandingan untuk referensi ilmu pengetahuan dan juga menambah wawasan yang baru untuk penelitian berikutnya.

\section{UCAPAN TERIMAKASIH}

Terimakasih kepada semua pihak yang sudah berkontribusi dalam penelitian ini sehingga dapat terlaksana dengan baik.

\section{DAFTAR PUSTAKA}

Ausaf Ahmad, "Development and Problems of Islamic Bank, Islamic Research and Training Institute Islamic Development Bank", Jeddah,1987.

Davis, F.D. "Perceived usefulness, perceived ease of use, and user acceptance of information technology". MS Quarterly (online), Vol. 13 Iss. 3, pg. 318, 1989.

Ghozali, Imam. "Aplikasi Analisis Multivariate dengan Program SPSS". Badan Penerbit Universitas Diponegoro, Semarang, 2013. 
"Aplikasi Analisis

Multivariente dengan Program IBM

SPSS 23",Cetakan VII, Badan Penerbit

Universitsas Dipenegoro, 2016.

Hadri Kusuma dan Dwi

Susilowati."Determinan

Pengadopsian Layanan Internet

Banking: Perspektif Konsumen

Perbankan Daerah Intimewa

Yokyakarta".Jurnal JAAI, Vol. 125, No. 2. 2007.

Hoyer, Wayne D. dan Maclnnis, Deborah J.

"Consumer Behavior". South-

Western. Cangage Learning. 2010.

Jogiyanto." Sistem Informasi Keprilakuan", Yogyakarta, 2007.

Kasmir. S.E., M.M. "Bank dan Lembaga Keuangan Lainnya”. Jakarta: PT. Raja Grafindo Persada. 2014.

Kotler, Philip dan Kevin Lane Keller. "Manajemen Pemasaran I", Edisi 12 Jilid 1, Jakarta: PT Indeks, 2007.

"Manajemen Pemasaran", Edisi 13 Jilid 1, Jakarta: Penerbit Erlangga, 2009.

"Marketing Management". Global Edition 13, Pearson Prentice Hall.Inc, New Jersey, 2012.

Leeraphong dan Mardjo. "Trust and Risk in Purchase Intenation throught Online Social Network". Jurnal of Economic Business and Management, Vol. 1, No. 4. 2013

Lovelock, Christopher H. dan Lauren K. Wright. "Manajemen Pemasaran Jasa”, Cetakan II, Indeks, Jakarta, 2007.

Mislah Hayati dan Sutisna. "Faktor-Faktor yang Mempengaruhi Minat Nasabah Terhadap Internet Banking". Vol.1, No.1. 2015.

Muhammad. "Manajemen Bank Syari'ah", edisi revisi cet. ke-2, Yogyakarta: UPP STIM YKPN, 2011.

Park, S.Y. "An Analysis of the Technology Acceptance Model in Understanding University Students' Behavioral
Intention to Use e-Learning Educational Technology \& Society, 12 (3), 150-162, 2009.

Pavlou, Fred "Perceived Usefulnes, Perceived Ease of Use and User Acceptance of Information Technology", MIS Quarterly, September, 2001.

Perdita Sari, Risky. "Pengaruh Persepsi manfaat, kemudahan, dan resiko terhadap menggunakanan Internet Banking nasabah bank Mandiri di Surabaya", 2017.

Raies Ahmad, Rifat Arad and Dr. Altaf., "Customer Attitude and Factors Influencing Users Acceptance of EBanking in $J \& K$ ”. International Journal of Business and Management Invention. Vol 2, July, 2013.

Sugiyono. "Metode Penelitian Bisnis", Alfabeta, Bandung, 2013.

, "Metode Penelitian Kuantitatif Kualitatif dan $R \& D$, Alfabeta, Bandung, 2015.

Sun, Heshan and Ping Zhang. "Causal Relationship Between Perceived Enjoyment and Perceived Ease of Use: An Alternatif Apporach". Journal of the Association for Information Systems 7 (9), 2006.

Supriyadi. "Pengaruh Persepsi Teknologi Informasi, Kemudahan Menggunakanan, Resiko Transaksi, dan fitur layanan terhadap peggunaan internet banking BCA Purworejo". Vol. 4 No. 12, 2014.

Umar, Fadzilah. "Pengaruh Kenyamanan, Kepercayaan, dan Kelengkapan fitur terhadap keputusan menggunakan internet Bangking", 2014.

Yudha, Hafid Nur. "Analisis Pengaruh Persepsi Nasabah Perbankan Terhadap Internet Banking Adoption (Studi Pada Nasabah Perbankan Yang Pengguna Internet Banking Di Kota Surakarta)". Vol 4, No 4, 2015.

https://ojk.go.id

https://bi.go.id

https://sharingvision.com 